\title{
ANALISIS LAPORAN KEUANGAN DALAM MENILAI KINERJA KEUANGAN PT MANDOM INDONESIA TBK PERIODE TAHUN 2015- 2018
}

\section{Moh. Zaki Kurniawan}

Jurusan Manajemen Fakultas Ekonomi dan Bisnis Universitas Trunojoyo Madura Email: zaki.kurniawan@trunojoyo.ac.id

\begin{abstract}
The purpose of this study was to determine the liquidity ratios, solvency ratios, profitability ratios, activity ratios, and growth ratios for the period 2015-2018. Analaisin liquidity ratios use current ratio, solvency ratios use debt to assets ratio and debt to equity ratio, profitability ratios use, activity ratios use return on assets and return on investment, growth ratios use sales growth, net profit growth, earnings growth per share.

The results of the analysis of the financial performance of PT Mandom Indonesia Tbk: 1) Liquidity ratio in healthy criteria, 2) Solvency ratio using debt to asset ratio in healthy criteria, and debt to equity ratio in healthy criteria, 3) Profitability ratio using return on assets (ROA) in the healthy criteria, and return on equity (ROE) in the less healthy criteria. 4) Activity ratio using total assets turnover ratio in unhealthy criteria, 5) Growth ratio using sales has increased, net income has decreased, and earnings per share has increased.
\end{abstract}

Keywords: liquidity ratio, solvency ratio, profitability ratio, activity ratio, and growth ratio.

\section{PENDAHULUAN}

Laporan keuangan dibuat dengan tujuan untuk memberikan gambaran dan informasi yang jelas bagi para pengguna laporan keuangan terutama bagi manajemen suatu perusahaan. Laporan keuangan bermanfaat sebagai bahan pertimbangan dan masukan dalam proses pengambilan keputusan demi kemajuan perusahaan dimasa yang akan datang. Informasi yang terdapat pada laporan keuangan diolah untuk menghasilkan berbagai informasi mengenai keadaan perusahaan kepada berbagai pihak yang berkepentingan seperti kreditur, pemegang saham, manajemen pemerintah, karyawan, akuntan publik, dan lainlain.

Analisis laporan keuangan menggunakan perhitungan rasio untuk mempermudah dalam mengevaluasi keadaan finansial perusahaan dimasa lalu, 
saat ini, dan masa yang akan datang. Rasio keuangan adalah kegiatan membandingkan angka-angka yang ada dalam laporan keuangan dengan cara membagi satu angka dengan angka lainnya, perbandingan dapat dilakukan antara satu komponen dengan komponen lain dalam satu laporan keuangan atau antara komponan yang ada diantara laporan keuangan (Kasmir, 2018:104).

Rasio dapat dihitung berdasarkan sumber datanya, mulai dari neraca maupun laporan laba rugi. Rasio yang dapat digunakan antara lain rasio likuiditas, rasio solvabilitas, rasio profitabilitas, dan rasio aktivitas.

Rasio likuiditas merupakan rasio yang digunakan untuk mengukur kemampuan perusahaan dalam memenuhi kewajiban jangka pendek dengan melihat aktiva lancar perusahaan terhadap hutang lancarnya (Hanafi dan Halim, 2018:75). Rasio solvabilitas merupakan rasio yang digunakan untuk mengukur kemampuan perusahaan memenuhi kewajiban-kewajiban jangka panjangnya (Hanafi dan Halim, 2018:79). Rasio profitabilitas merupakan rasio yang digunakan untuk mengukur kemampuan perusahaan dalam menghasilkan laba pada tingkat penjualan, aset, dan modal saham tertentu (Hanafi dan Halim, 2018:79). Rasio aktivitas merupakan rasio yang digunakan untuk mengukur sejauh mana efektifitas penggunaan aset dengan melihat tingkat aktivitas aset (Hanafi dan Halim, 2018:76).Rasio pertumbuhan yaitu rasio yang mengukur seberapa besar kemampuan perusahaan dalam mempertahankan posisinya di dalam industri dan dalam perkembangan ekonomi secara umum (Fahmi, 2017:137).

Kinerja keuangan perusahaan dapat diartikan sebagai prospek atau masa depan, pertumbuhan, dan potensi perkembangan bagi perusahaan. Informasi kinerja keuangan diperlukan untuk menilai perubahan potensial sumber daya ekonomi, yang mungkin dikendalikan dimasa depan dan untuk memproduksi kapasitas produksi dari sumber daya yang ada. Evaluasi kinerja keuangan dapat dilakukan dengan menggunakan analisis laporan keuangan, dimana data pokok sebagai input dalam analisis tersebut adalah neraca dan laporan laba rugi.

Perusahaan manufaktur merupakan salah satu sektor yang ada di Bursa Efek Indonesia. Salah satu perusahaan manufaktur yang terdapat di BEI adalah PT Mandom Indonesia Tbk yang mencatatkan pendapatan yang relatif berfluktuasi 
pada kurun waktu 2015-2018. Perbandingan antara aset dan laba bersih PT Mandom Indonesia Tbk dapat dijelaskan pada tabel berikut:

Tabel 1 Total Aset Dan Total Laba Bersih PT Mandom Indonesia Tbk.

\begin{tabular}{|ccc}
$\underline{\text { Tahun }}$ & Total Aset & Laba Bersih \\
\hline 2015 & 2.082 .096 .848 .703 & 544.474 .278 .014 \\
2016 & 2.185 .101 .038 .101 & 162.059 .569 .347 \\
\hline 2017 & 2.361 .807 .189 .430 & 179.126 .382 .068 \\
\hline 2018 & 2.445 .143 .511 .801 & 173.049 .442 .756 \\
\hline
\end{tabular}

sumber: www.idx.co.id (2019)

Data diatas menunjukkan bahwa total aset setiap tahunnya mengalami kenaikan, tetapi laba bersih yang diperoleh mengalami penurunan dan peningkatan (fluktuatif). Tahun 2016 laba bersih yang diperoleh PT Mandom Indonesia Tbk mengalami penurunan yang sangat drastis dibanding tahun 2015 .

Berdasarkan uraian diatas, maka peneliti tertarik untuk melakukan analisis dengan tujuan mengetahui lebih lanjut mengenai kesehatan kinerja keuangan PT Mandom Indonesia Tbk (Periode Tahun 2015-2018) dengan menggunakan rasio keuangan: rasio likuiditas, rasio solvabilitas, rasio profitabilitas, dan rasio aktivitas.

\section{METODE PENELITIAN}

\section{Jenis dan Sumber Data}

Jenis data yang digunakan adalah data kuantitaif yang berupa data sekunder yaitu laporan keuangan PT. Mandom Indonesia Tbk dari website Bursa Efek Indonesia (BEI) www.idx.co.id.

Lingkup objek penelitian mengenai analisis laporan keuangan perusahaan dengan menggunakan rasioli kuiditas, rasio solvabilitas, rasio profitabilitas, rasio aktifitas dan rasio pertumbuhan terhadap penilaian kinerjakeuangan PT. Mandom IndonesiaTbk Periode tahun 2015-2018. 


\section{Indikator Pengukuran}

Tabel 2 Indikator Pengukuran

\begin{tabular}{|c|c|c|c|}
\hline No. & $\begin{array}{c}\text { Jenis } \\
\text { Pengukuran }\end{array}$ & Analisis & Rumus \\
\hline 1. & Rasio Likuiditas & Current Ratio & $\begin{array}{c}\frac{\text { AktivaLancar }}{\text { HutangLancar }} \\
\text { Sumber : Hanafi dan Halim, 2018:75 }\end{array}$ \\
\hline \multirow{2}{*}{2.} & \multirow{2}{*}{$\begin{array}{c}\text { Rasio } \\
\text { Solvabilitas }\end{array}$} & $\begin{array}{l}\text { Debt to Assets } \\
\quad \text { Ratio }\end{array}$ & $\begin{array}{c}\frac{\text { Total Hutang }}{\text { Total Aset }} \\
\text { Sumber : HanafidanHalim, 2018:79 }\end{array}$ \\
\hline & & $\begin{array}{l}\text { Debt to Equity } \\
\quad \text { Ratio }\end{array}$ & $\frac{\text { Total Hutang }}{\text { Modal }}$ \\
\hline \multirow{2}{*}{3.} & \multirow{2}{*}{$\begin{array}{c}\text { Rasio } \\
\text { Profitabilitas }\end{array}$} & $\begin{array}{l}\text { Return On } \\
\text { Assets }\end{array}$ & $\begin{array}{c}\frac{\text { LabaBersih }}{\text { TotalAset }} \\
\text { Sumber : Hanafi dan Halim, 2018:81 }\end{array}$ \\
\hline & & $\begin{array}{l}\text { Return On } \\
\text { Equity }\end{array}$ & $\begin{array}{c}\frac{\text { LabaBersih }}{\text { Modal }} \\
\text { Sumber : Hanafi dan Halim, 2018:82 }\end{array}$ \\
\hline 4. & Rasio Aktivitas & $\begin{array}{l}\text { Total Assets } \\
\text { Turnover Ratio }\end{array}$ & $\begin{array}{c}\frac{\text { Penjualan }}{\text { Total Aktiva }} \\
\text { Sumber : Kasmir, 2018:177 }\end{array}$ \\
\hline \multirow{5}{*}{5.} & \multirow{5}{*}{$\begin{array}{c}\text { Rasio } \\
\text { Pertumbuhan }\end{array}$} & $\begin{array}{l}\text { Pertumbuhan } \\
\text { Penjualan }\end{array}$ & $\begin{array}{c}\text { Penjualan tahun } \mathrm{t}_{\mathrm{t}}-\text { Penjualan tahun }_{\mathrm{t}-1} \\
\text { Penjualan tahun } \mathrm{t}-1 \\
\text { Sumber : Kasmir, 2016:193 }\end{array}$ \\
\hline & & \multirow{2}{*}{$\begin{array}{l}\text { Pertumbuhan } \\
\text { Laba Bersih }\end{array}$} & Laba bersih tahun $\mathrm{t}_{\mathrm{t}}-$ Laba bersih tahun $\mathrm{t}$ - \\
\hline & & & $\begin{array}{c}\text { Laba bersih tahun } \mathrm{t}-1 \\
\text { Sumber : Kasmir, 2016: } 193\end{array}$ \\
\hline & & \multirow{2}{*}{$\begin{array}{l}\text { Pertumbuhan } \\
\text { Pendapatan Per } \\
\text { Tahun }\end{array}$} & Laba per saham $\operatorname{tahun}_{t}-$ Laba per saham \\
\hline & & & $\begin{array}{l}\text { Laba per saham tahun } \\
\text { t-1 } \\
\text { Sumber : Kasmir, 2016:193 }\end{array}$ \\
\hline
\end{tabular}

\section{Teknik Analisis Data}

Gambar 1 Teknik Analisis Data

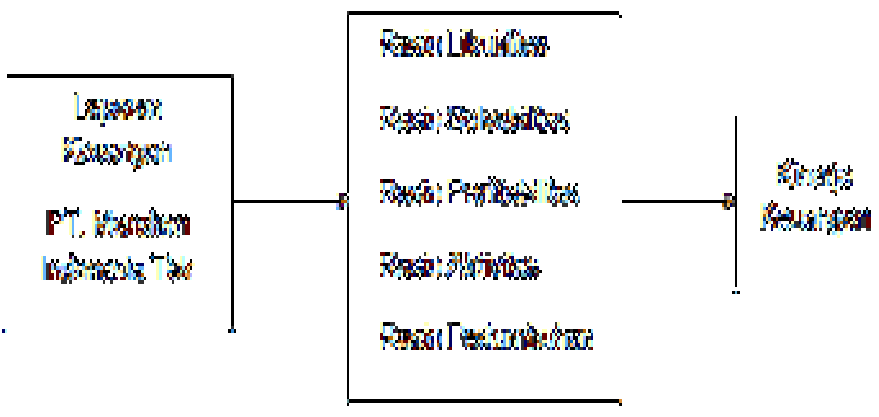




\section{HASIL DAN PEMBAHASAN PENELITIAN}

\section{Rasio Likuiditas}

Analisis Current Ratio

Tabel 3 Perhitungan Current Ratio

\begin{tabular}{c|cccc|}
\hline Tahun & Aktiva Lancar & Hutang Lancar & Hasil & Kriteria \\
\hline 2015 & 1.112 .672 .539 .416 & 222.930 .621 .643 & $499,11 \% / 1$ & Sehat \\
\hline 2016 & 1.174 .482 .404 .487 & 223.305 .151 .868 & $525,95 \%$ & Sehat \\
\hline 2017 & 1.276 .478 .591 .542 & 259.806 .845 .843 & $491,32 \%$ & Sehat \\
\hline 2018 & 1.333 .428 .311 .186 & 231.533 .842 .787 & $575,91 \%$ & Sehat \\
\hline
\end{tabular}

Sumber: data diolah, 2019

Hasil perhitungan current ratio PT Mandom Indonesia Tbk periode tahun 2015 sampai dengan tahun 2018 terjadi fluktuatif. Tahun 2015 sampai dengan tahun 2018 masuk dalam kriteria sehat, penilaian tersebut sesuai dengan Peraturan Menteri Negara Koperasi dan Usaha Kecil dan Menengah Republik Indonesia, Nomor 06/Per/M.KUKM/V/2006 tanggal 1 Mei 2006. PT Mandom Indonesia Tbk mampu memenuhi kewajiban jangka pendeknya meskipun dalam tiap tahunnya mengalami peningkatan dan penurunan. Current Ratio merupakan rasio yang mengukur kemampuan perusahaan memenuhi hutang jangka pendek menggunakan aktiva lancar (Hanafi dan Halim, 2018:75). Hasil penilaian ini sejalan dengan hasil penelitian Supra (2018) menyatakan bahwa hasil kinerja keuangan PT Taiso Pharmaceutical Indonesia dengan rasio likuiditas menggunakan current ratio berada pada kategori baik. Satria (2017) menyatakan bahwa hasil kinerja keuangan PT Derma Henwa Tbk dengan rasio likuiditas menggunakan rasio lancar (current ratio) dalam keadaan sehat. Rahmah dan Komariah (2016) menyatakan bahwa hasil kinerja keuangan PT Indocement Tunggal Prakarsa Tbkdengan rasio likuiditas menggunakan rasio lancar (current ratio) berada di atas rata-rata dengan kata lain perusahaan masuk dalam kriteria baik atau mampu melunasi hutang jangka pendeknya. Zega, Johan, dan Riadi (2015) menyatakan bahwa hasil kinerja keuangan CV Siak Sejahtera dengan rasio likuiditas menggunakan rasio lancar (current ratio) menunjukkan kinerja yang baik atau liquid karena aktiva lancar yang tersedia mampu menjamin kewajiban lancar perusahaan. 


\section{Rasio Solvabilitas}

\section{Analisis Debt to Assets Ratio}

Tabel 4 Perhitungan Debt to Assets Ratio

\begin{tabular}{|c|c|c|c|c|}
\hline & 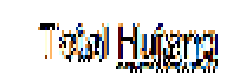 & 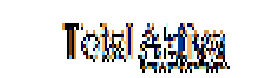 & 4 & Sigy \\
\hline & 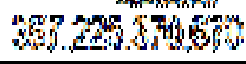 & 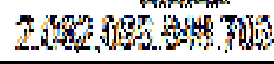 & $17,6 \%$ & $8 \times h^{2}$ \\
\hline 215 & AYY & 2. & 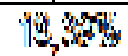 & Sothe \\
\hline 2017 & 20 , & 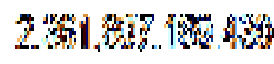 & 21,4 & Solsh \\
\hline 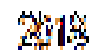 & 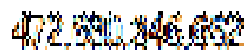 & 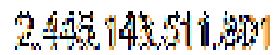 & 93 & 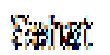 \\
\hline
\end{tabular}

Sumber : data diolah, 2019

Hasil perhitungan Debt to Assets Ratio PT Mandom Indonesia Tbk periode tahun 2015 sampai dengan tahun 2018 terjadi fluktuatif. Tahun 2015 sampai dengan tahun 2018 masuk dalam kriteria sehat, penilaian tersebut sesuai dengan Peraturan Menteri Negara Koperasi dan Usaha Kecil dan Menengah Republik Indonesia, Nomor 06/Per/M.KUKM/V/2006 tanggal 1 Mei 2006. PT Mandom Indonesia Tbk mampu memenuhi kewajiban jangka panjangnya meskipun dalam tiap tahunnya mengalami peningkatan dan penurunan. Rasio Total Hutang Terhadap Total Aset merupakan rasio yang digunakan untuk mengukur perbandingan antara total hutang dengan total aktiva (Hanafi dan Halim, 2018:79). Hasil penelitian ini sesuai dengan penelitian Supra (2018) menyatakan bahwa hasil kinerja keuangan PT Taiso Pharmaceutical Indonesia dengan rasio solvabilitas menggunakan debt ratio berada pada kategori baik. Rahmah dan Komariah (2016) menyatakan bahwa hasil kinerja keuangan PT Indocement Tunggal Prakarsa Tbk dengan rasio solvabilitas menggunakan debt to assets ratio berada di atas rata-rata dengan kata lain perusahaan masuk dalam kriteria baik atau mampu melunasi hutang jangka panjangnya. Erakipia dan Gamaliel (2016) menyatakan bahwa hasil kinerja keuangan UMKM Amungme dan Kamoro dengan rasio solvabilitas menggunakan debt to assets ratio menunjukkan bahwa perusahaan mampu menutupi hutanghutangnya. Zega, Johan, dan Riadi (2015) menyatakan bahwa hasil kinerja keuangan CV Siak Sejahtera dengan rasio solvabilitas menggunakan debt to assets ratio menunjukkan kinerja yang baik. 


\section{Analisis Debt to Equity Ratio}

Tabel 5 Perhitungan Debt to Equity Ratio

\begin{tabular}{c|c|cc|c|} 
Tahun & Total Hutang & Modal & Hasil & Kriteria \\
2015 & 367.225 .370 .670 & 1.714 .871 .478 .033 & $21,41 \%$ & Sehat \\
\hline 2016 & 401.942 .530 .776 & 1.783 .158 .507 .325 & $22,54 \%$ & Sehat \\
\hline 2017 & 503.480 .853 .006 & 1.858 .326 .336 .424 & $27,09 \%$ & Sehat \\
\hline 2018 & 472.680 .346 .662 & 1.972 .463 .165 .139 & $23,96 \%$ & Sehat \\
\hline
\end{tabular}

Sumber : data diolah, 2019

Hasil perhitungan Debt to Equity Ratio PT Mandom Indonesia Tbk periode tahun 2015 sampai dengan tahun 2018 terjadi fluktuatif. Tahun 2015 sampai dengan tahun 2018 masuk dalam kriteria sehat, penilaian tersebut sesuai dengan Peraturan Menteri Negara Koperasi dan Usaha Kecil dan Menengah Republik Indonesia, Nomor 06/Per/M.KUKM/V/2006 tanggal 1 Mei 2006. PT Mandom Indonesia Tbk mampu memenuhi kewajiban jangka panjangnya meskipun dalam tiap tahunnya mengalami peningkatan dan penurunan. Rasio Hutang dengan Modal Sendiri merupakan rasio yang digunakan untuk membandingkan seluruh hutang termasuk hutang lancar dengan seluruh modal (Kasmir, 2018:157). Hasil penelitian ini sejalan dengan Supra (2018) menyatakan bahwa hasil kinerja keuangan PT Taiso Pharmaceutical Indonesia dengan rasio solvabilitas menggunakan debt to equity ratio berada pada kategori baik. Pohan (2017) menyatakan bahwa hasil kinerja keuangan PT Tiga Pilar Sejahtera Food Tbk dengan rasio solvabilitas menggunakan debt to equity ratio berada pada kategori baik. Rahmah dan Komariah (2016) menyatakan bahwa hasil kinerja keuangan PT Indocement Tunggal Prakarsa Tbk dengan rasio solvabilitas menggunakan debt to equity ratio berada di atas rata-rata dengan kata lain perusahaan masuk dalam kriteria baik atau mampu melunasi hutang jangka panjangnya. Erakipia dan Gamaliel (2016) menyatakan bahwa hasil kinerja keuangan UMKM Amungme dan Kamoro dengan rasio solvabilitas menggunakandebt to equity ratio menunjukkan bahwa perusahaan mampu menutupi hutang-hutangnya. Zega, Johan, dan Riadi (2015) menyatakan bahwa hasil kinerja keuangan CV Siak Sejahtera dengan rasio solvabilitas menggunakan debt to assets ratio menunjukkan kinerja yang baik. 


\section{Rasio Profitabilitas}

\section{Return On Assets (ROA)}

Tabel 6 Perhitungan Return On Assets

\begin{tabular}{c|cc|c|c|} 
Tahun & Laba Bersih & Total Aktiva & Hasil & Kriteria \\
2015 & 544.474 .278 .014 & 2.082 .096 .848 .703 & $26,15 \%$ & Sehat \\
\hline 2016 & 162.059 .569 .347 & 2.185 .101 .038 .101 & $7,42 \%$ & Cukup Sehat \\
2017 & 179.126 .382 .068 & 2.361 .807 .189 .430 & $7,58 \%$ & Cukup Sehat \\
2018 & 173.049 .442 .756 & 2.445 .143 .511 .801 & $7,08 \%$ & Cukup Sehat
\end{tabular}

Sumber : data diolah, 2019

Hasil perhitungan Return On Assets PT Mandom Indonesia Tbk periode tahun 2015 sampai dengan tahun 2018 terjadi fluktuatif. Tahun 2015 hasil perhitungan ROA PT Mandom Indonesia Tbk masuk dalam kriteria sehat. Tahun 2016 mengalami penurunan yang sangat drastis, hingga tahun 2018 meski mengalami peningkatan dan penurunan hasil dalam kurun waktu tersebut belum mampu melampaui hasil di tahun 2015. Tahun 2016 hingga 2018 masuk dalam kriteria cukup sehat. Rata-rata perhitungan periode tahun 2015 sampai 2018 masuk dalam kriteria sehat. Penilaian tersebut sesuai dengan Peraturan Menteri Negara Koperasi dan Usaha Kecil dan Menengah Republik Indonesia, Nomor 06/Per/M.KUKM/V/2006 tanggal 1 Mei 2006. ROA merupakan rasio untuk mengukur kemampuan perusahaan menghasilkan laba bersih berdasarkan tingkat aset yang tertentu. Hasil penelitian ini sejalan dengan Supra (2018) menyatakan bahwa hasil kinerja keuangan PT Taiso Pharmaceutical Indonesia dengan rasio profitabilitas menggunakan return on assets berada pada kategori baik. Trianto (2017) menyatakan bahwa hasil kinerja keuangan PT Bukit Asam (Persero) Tbk Tanjung Enim dengan rasio profitabilitas menggunakan return on investment mengalami penurunan tetapi rata-rata hasil perhitungan masih masuk dalam kategori baik, penurunan yang terjadi karena tingkat kenaikan laba bersih setelah pajak lebih rendah dari total aktiva. 


\section{Return On Equity (ROE)}

Tabel 7 Perhitungan Return On Equity

\begin{tabular}{|c|c|c|c|c|}
\hline Trixin & Lox Exyle & Misid & Het: & Exycy \\
\hline STIF & 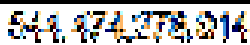 & $1, \bar{\beta}+4.40$ & 31,396 & zestont \\
\hline 2713 & 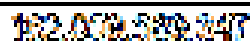 & 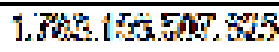 & $3004:$ & 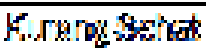 \\
\hline $3 \pi \%$ & 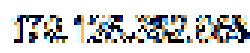 & 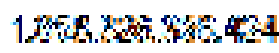 & $204 \%$ & 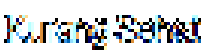 \\
\hline 要倦 & 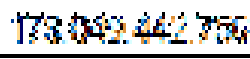 & 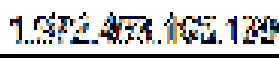 & 多㚏殁官 & 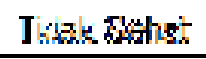 \\
\hline
\end{tabular}

Sumber : data diolah, 2019

Hasil perhitungan Return On Equity PT Mandom Indonesia Tbk periode tahun 2015 sampai dengan tahun 2018 terjadi fluktuatif. Tahun 2015 hasil perhitungan ROE PT. Mandom Indonesia Tbk masuk dalam kriteria sehat. Tahun 2016 mengalami penurunan yang sangat drastis, hingga tahun 2018 meski menalami peningkatan dan penurunan hasil dalam kurun waktu tersebut belum mampu melampaui hasil di tahun 2015. Tahun 2016 sampai 2017 masuk dalam katergori kurang sehat.Tahun 2018 masuk dlam kategori tidak sehat. Penilaian tersebut sesuai dengan Peraturan Menteri Negara Koperasi dan Usaha Kecil dan Menengah Republik Indonesia, Nomor 06/Per/M.KUKM/V/2006 tanggal 1 Mei 2006. ROE merupakan rasio untuk mengukur kemampuan perusahaan menghasilkan laba bersih berdasarkan modal tertentu (Hanafi dan Halim, 2018:82). Hasil penelitian ini sejalan dengan Trianto (2017) menyatakan bahwa hasil kinerja keuangan PT Bukit Asam (Persero) Tbk Tanjung Enim dengan rasio profitabilitas menggunakan return on equity menunjukkan kinerja keuangan perusahaan kurang baik. Pohan (2017) menyatakan bahwa hasil kinerja keuangan PT Tiga Pilar Sejahtera Food Tbk dengan rasio profitabilitas menggunakan return on equity menunjukkan kinerja keuangan perusahaan kurang baik. Rahmah dan Komariah (2016) menyatakan bahwa hasil kinerja keuangan PT Indocement Tunggal Prakarsa Tbk dengan rasio profitabilitas menggunakan return on equity menunjukkan kinerja keuangan perusahaan di nilai kurang baik karena perusahaan belum mampu memperoleh ROE. Zega, Johan, dan Riadi (2015) menyatakan bahwa hasil kinerja keuangan CV Siak Sejahtera dengan rasio profitabilitas menggunakan return on equity menunjukkan kinerja keuangan perusahaan kurang baik. 


\section{Rasio Aktivitas}

\section{Analisis Total Assets Turnover Ratio}

Tabel 8 Perhitungan Total Assets Turnover Ratio

\begin{tabular}{|c|c|c|c|c|}
\hline Thatitum & 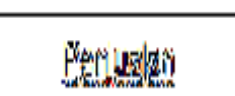 & 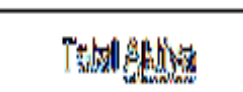 & 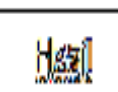 & 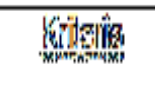 \\
\hline $2 x^{5}$ & 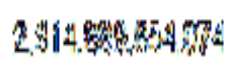 & 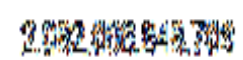 & 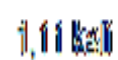 & 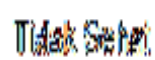 \\
\hline 20 & 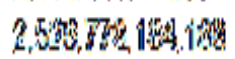 & 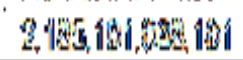 & 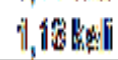 & Misis \\
\hline 2918 & 27063428 & 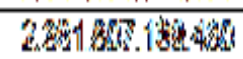 & 1, 佔btii & 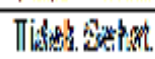 \\
\hline 24 & 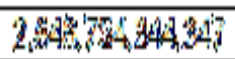 & 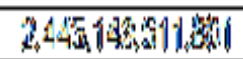 & 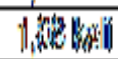 & 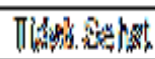 \\
\hline
\end{tabular}

Sumber : data diolah, 2019

Hasil perhitungan total assets turnover ratio PT Mandom Indonesia Tbk periode tahun 2015 sampai dengan tahun 2018 cenderung terjadi penurunan dan mengalami sedikit peningkatan. Tahun 2015 sampai dengan tahun 2018 hasil perhitungan PT Mandom Indonesia Tbk masuk dalam kriteria tidak sehat. Penilaian tersebut sesuai dengan Peraturan Menteri Negara Koperasi dan Usaha Kecil dan Menengah Republik Indonesia, Nomor 06/Per/M.KUKM/V/2006 tanggal 1 Mei 2006. Perputaran total aktiva (total assets turnover ratio) merupakan rasio yang digunakan untuk mengukur perputaran semua aktiva yang dimiliki perusahaan dengan melihat jumlah penjualan yang diperoleh dari tiap aktiva (Kasmir, 2018:177). Penelitian ini sejalan dengan Lubis dan Hafni (2017) menyatakan bahwa hasil kinerja keuangan Pemerintah Daerah Kabupeten Labuhan Batu Tahun Anggaran 2011-2013 masuk dalam kriteria tidak baik.

\section{Rasio Pertumbuhan PT. Mandom Indonesia Tbk}

\section{Pertumbuhan Penjualan}

Tabel 9 Perhitungan Pertumbuhan Penjualan

\begin{tabular}{cc|c|}
\hline Tahun & Penjualan & Pertumbuhan \\
\hline 2015 & 2.314 .889 .854 .074 & - \\
\hline 2016 & 2.526 .776 .164 .168 & $9 \%$ \\
\hline 2017 & 2.706 .394 .847 .919 & $7 \%$ \\
2018 & 2.648 .754 .344 .347 & $-2 \%$ \\
\hline
\end{tabular}

Sumber : data diolah, 2019

Hasil perhitungan pertumbuhan penjualan PT Mandom Indonesia Tbk periode tahun 2015 sampai dengan tahun 2018 mengalamai peningkatan meski di tahun 2018 mengalami sedikit penurunan, hasil tersebut masih dinilai baik karena 
peningkatan lebih besar dibanding penurunan yang dialami. Pertumbuhan penjualan menunjukan sejauh mana perusahaan dapat meningkatkan penjualannya dibandingkan dengan total penjualan secara keseluruhan (Kasmir, 2016:193). Hasil perhitungan menunjukkan bahwa perusahaan mampu meningkatkan penjualan dibanding dengan total penjualan secara keseluruhan, sehingga perusahaan di anggap baik.

\section{Pertumbuhan Laba Bersih}

Tabel 10 Perhitungan Pertumbuhan Laba Bersih

\begin{tabular}{|c|c|c|}
\hline 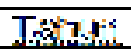 & 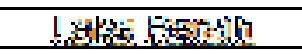 & Pistoming \\
\hline 2816 & 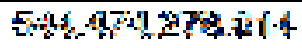 & - \\
\hline 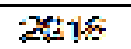 & 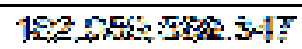 & -’ive \\
\hline 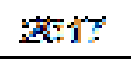 & 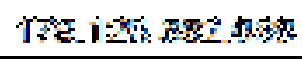 & $11^{13}$ \\
\hline 转婊 & 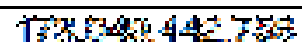 & 3.6 \\
\hline
\end{tabular}

Sumber : data diolah, 2019

Hasil perhitungan pertumbuhan laba bersih PT Mandom Indonesia Tbk periode tahun 2015 sampai dengan tahun 2018 mengalami banyak sekali penurunan, hal tersebut di anggap membahayakan perusahaan. Pertumbuhan laba bersih menunjukan sejauh mana perusahaan dapat meningkatkan kemampuannya untuk memperoleh keuntungan bersih dibandingkan dengan total keuntungan secara keseluruhan (Kasmir, 2016:193). Perusahaan kurang mampu meningkatkan kemampuaanya dalam memperoleh laba dibandingkan dengan total keuntungan secara keseluruhan, tetapi perusahaan masih mampu menutupi kewajibankewajiban yang harus dibayar.

\section{Pertumbuhan Pendapatan Per Saham}

Tabel 11 Pertumbuhan Pendapatan Per Saham

\begin{tabular}{|c|c|c|}
\hline 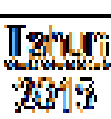 & 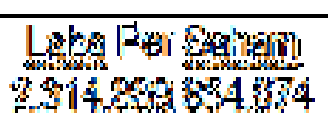 & 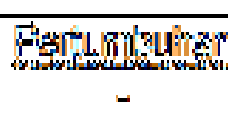 \\
\hline 20 & 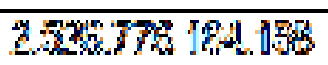 & 89 \\
\hline खणा: & $57 x 6364$ & 79G \\
\hline $21 \%$ & 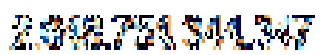 & Fax \\
\hline
\end{tabular}

Sumber : data diolah, 2019

Hasil perhitungan pertumbuhan pendapatan per saham PT Mandom Indonesia Tbk periode tahun 2015 sampai dengan tahun 2018 peningkatan meski di tahun 2018 mengalami sedikit penurunan, hasil tersebut masih dinilai baik karena 
peningkatan lebih besar dibanding penurunan yang dialami. Pertumbuhan pendapatan per saham menunjukan sejauh mana perusahaan dapat meningkatkan kemampuannya untuk memperoleh pendapatan atau laba per lembar saham dibandingkan dengan total laba per saham secara keseluruhan (Kasmir, 2016:193). Perusahaan dinilai mampu meningkatkan kemampuannya dalam memperoleh laba per lembar saham yang rasio nya sejalan dengan pertumbuhan penjualan.

\section{KESIMPULAN DAN REKOMENDASI}

\section{Kesimpulan}

1. Rasio likuiditas kinerja keuangan PT Mandom Indonesia Tbk periode tahun 2015-2018 menggunakan current ratio masuk dalam kriteria sehat.

2. Rasio solvabilitas kinerja keuangan PT Mandom Indonesia Tbk periode tahun 2015-2018 menggunakan debt to asset ratio masuk dalam kriteria sehat, dan debt to equity ratio masuk dalam kriteria sehat.

3. Rasio profitabilitas kinerja keuangan PT Mandom Indonesia Tbk periode tahun 2015-2018 menggunakan return on assets (ROA) masuk dalam kriteria sehat, dan return on equity (ROE) masuk dalam kriteria kurang sehat.

4. Rasio aktivitas kinerja keuangan PT Mandom Indonesia Tbk periode tahun 2015-2018 menggunakan total assets turn over ratio masuk dalam kriteria tidak sehat.

5. Rasio pertumbuhan kinerja keuangan PT Mandom Indonesia Tbk periode tahun 2015-2018 menggunakan pertumbuhan penjualan mengalami peningkatan, pertumbuhan laba bersih mengalami penurunan, dan pertumbuhan pendapatan per saham mengalami peningkatan.

\section{Rekomendasi}

Peneliti selanjutnya perlu mencoba menggunakan rasio pasar untuk mengukur kinerja keuangan yang digunakan untuk menunjukkan sejauh mana investor saham menilai layak tidaknya harga saham untuk dibeli.

\section{DAFTAR PUSTAKA}

Erakipia, Apolonaris Felix., dan Hendrik Gamaliel. (2016). Analisis Laporan Keuangan Sebagai Dasar Penilaian Kinerja Keuangan Pada UMKM Amugnme dan Kamoro. Jurnal EMBA. 5 (1): 38-46. 
Fahmi, Irham. 2017. Analisis Laporan Keuangan. Jakarta: Alfabeta.

Hanafi, Mamduh M., dan Abdul Halim. 2018. Analisis Laporan Kueangan. Yogyakarta: UPP STIM YKPN.

Harahap, Sofyan Syafri. 2013. Analisis Kritis Atas Laporan Kuangan. Jakarta: Rajawali Pers.

Hery. 2015. Analisis Laporan Keuangan. Yogyakarta: Center For Academic Publishing service.

Kasmir. 2016. Analisis Laporan Keuangan. Jakarta: Rajawali Pers.

Kasmir. 2018. Analisis Laporan Keuangan. Jakarta: Rajawali Pers.

Laporan Keuangan PT. Mandom Indonesia Tbk dari www.idx.co.id.

Peraturan Menteri Negara Koperasi dan Usaha Kecil dan Menengah Republik Indonesia nomor 06/Per/M.KUKM/V/2006 tentang Pedoman Penilaian Koperasi Berprestasi/koperasi award.

Pohan, Safriadi. (2017). Analisis Laporan Keuangan Untuk Mengukur Kierja Keuanan Pada Perusahaan Yang Go Public Di Bursa Efek Indonesia (StudiKasusPada PT. Tiga Pilar Sejahtera Foods Tb kPeriode 2011-2015). Jurnal Manajemen dan Informatika Komputer Pelita Nusantara. 1 (1): 7-11.

Rahmah, Mutia Nur., dan Euis Komariah. (2016). Analisis Laporan Keuangan Dalam Menilai Kinerja Keuangan Industri Semen Yang Terdaftar Di BEI (StudiKasus PT. Indocement Tunggal Prakarsa TBK). Jurnal Online Insan Akuntan.1 (1): 43-58.

Satria, Rita. (2017). Analisis Laporan Keuangan Untuk Melihat Kinerja Perusahaan Pada PT. Darma Henwa TBK. Jurnal Sekuritas. 1 (2): 89-102.

Supra, Deswati. (2018). Analisis Laporan Keuangan Dalam Menilai Kinerja Keuangan Pada PT. Taiso Pharmaceutical Indonesia. Jurnal Akuntanika. 4 (1): 38-48.

Sunyoto, Danang. 2016. Metodologi Penelitian Akuntansi. Bandung: PT. Refika Aditama.

Sutrisno. 2013. Manajemen Keuangan: Teori, Konsep, dan Aplikasi. Jakarta: Ekonisia.

Trianto, Anton. (2017). Analisis Laporan Keuangan Sebagai alat Untuk menilai kinerja Keuangan Perusahaan Pada PT. Bukit sam (Persero) TBK Tanjung Enim. Jurnal Ilmiah Ekonomi Global Masa Kini. 8 (03): 1-10.

Wahyudiono, Bambang. 2014. Mudah Membaca Laporan Keuangan. Jakarta: Swadaya Grup.

Zega, Herianto., Rina Selva Johan., dan RM Riadi. (2015). Analisis Laporan Keuangan Untuk Menilai Kinerja Keuangan Pada CV. Siak Sejahtera Periode 2010 s/d 2014. Jurnal Online Mahasiswa (JOM) Bidang Keguruan dan Ilmu Pendidikan. 2 (2): 1-14. 